\title{
Preaching matters: Replication and extension
}

\author{
Brooks B. Hull ${ }^{\mathrm{a}, *}$, Frederick Bold ${ }^{\mathrm{b}}$ \\ ${ }^{a}$ Department of Social Sciences, University of Michigan-Dearborn, Dearborn, MI 48128-1491, USA. \\ ${ }^{\mathrm{b}}$ Department of Economics and Department of Management, University of Nevada, Las Vegas, \\ Nevada, USA
}

Revised 1 September 1994

\begin{abstract}
Statistical evidence in a recent excellent paper by Lipford, McCormick, and Tollison shows a negative relationship between church membership and social misbehavior. This paper replicates that relationship using more comprehensive data by U.S. county. We provide theoretical support for the statistical evidence by showing that churches encourage appropriate behavior (thus providing property rights enforcement) because doing so benefits churches and their members. As church membership increases, property rights enforcement increases, although at a diminishing rate.
\end{abstract}

Keywords: Church; Religion; Property rights; Crime

JEL classification: K42; L39; Z00

\section{Introduction}

Statistical evidence reported in a recent excellent paper by Lipford et al. (1993) (hereafter L-M-T) shows a significant inverse relationship between church membership and various forms of social misbehavior. The results are compelling, but the authors acknowledge unresolved issues. First, L-M-T explicitly avoid dealing with the question of why churches might promote moral behavior: 'Religious sanctions, real and otherwise, are an interesting subject, but this paper does not

\footnotetext{
${ }^{*}$ Corresponding author
} 
seek to model enforcement behavior by the church(es)' (p. 237). As L-M-T recognize, church efforts to promote moral behavior help society. Not made clear, however, is the reason why doing so benefits the church. Without such a theoretic link, any observed correlation between church membership and crime may be spurious.

A second potential weakness of L-M-T's analysis is its use of U.S. state-level data. Although government actions to address moral issues often take place at the state level, state criminal laws being an example, religious activity typically takes place at the local level. Aggregate state data may not fully address the local nature of church membership and its effect on the community.

This paper's objective is to extend L-M-T's work by providing the framework of an economic theory of church behavior and by confirming the theory using less aggregated U.S. county data. We also test additional implications of the theory.

\section{Overview}

Despite significant differences in their doctrines regarding cosmology and their descriptions of divine authority, most religions, certainly the world's major religions, possess remarkably similar features. Included among these are a set of behavioral rules and belief in an afterlife. These characteristics are nearly pervasive in religions through history and across cultures (Hull and Bold (1994)).

We suggest that the similarities between religions are consistent with the notion that religions have the often unintended secular purpose of helping their host sncieties function successfully. The way this is accomplished is that - regardless of their stated or intended functions - churches and religions help establish and enforce a system of property rights.

The critical role explicit and well-defined property rights play in the smooth operation of an economy is widely recognized. Economists also recognize the importance of implicit property rights in the form of commonly-accepted norms, moral guidelines, and standards of behavior. Both Etzioni (1988) and Wilson (1993) argue persuasively that individual morality is as important or more important than formal law in encouraging behavior that protects property rights and so reduces transactions costs. Churches especially tend to promote rules of morality and behavior that are similar to or complement the moral standards that commonly emerge in human culture, standards which may be evolutionarily adaptive (Wilson (1993)).

Property rights enforcement is a public good and so shares the characteristic that charging those who benefit from provision of the public good is impractical or inefficient. For this reason, property rights enforcement is not normally provided by private suppliers. As L-M-T recognize, governments provide this public good by employing coercion and involuntary taxation (p. 236). A number of the 
common aspects of religions and churches can be explained as features that have evolved to serve this function as well. A simple example from Judeo-Christian doctrine is the commandment 'Thou shalt not steal', violation of which is cause for punishment by the religious group or in the afterlife.

Referring to the latter form of punishment, the potential impact of an omniscient and omnipotent god in monitoring good behavior and enforcing it in the afterlife is significant indeed and is acknowledged by writers like Frank (1988, p. 250) and Ellickson (1991, p. 237). This form of enforcement is unique to religions and gives them a comparative advantage in property rights enforccment under certain circumstances, especially when other methods are relatively less effective (Etzioni (1988, p. 242); Hull and Moran (1989)). The church's ability to enforce property rights is influenced by various factors including enforcement costs and the available technology of enforcement methods (Hull and Bold (1994)).

\section{Model}

Whatever their function, churches must support themselves; they must earn revenue in the form of money and member effort. Churches, like all voluntary organizations can expect to receive some donations purely to support production of valuable public goods as the literature on public goods and clubs shows (e.g. Sandler (1992); Sandler and Tschirhart (1980)). Another strategy is to tie production of the public good to production of one or more private goods (Sandler (1992, pp. 58-61)). As we show in other work, churches often provide a complex bundle of tied private and public goods, characterized by economies of scope (Hull and Bold (1989)).

However, regardless of the strategy employed, a key determinate of church revenue is the number of members. A church can be thought of as a group that gains collectively from additional members (e.g. Iannaccone (1992)) or, more simply, as a firm whose product is members. A church gains to the extent it is able to maximize revenue from member donations less cost:

$$
\pi=\mathrm{D} \cdot \mathrm{m}-\mathrm{C} \cdot \mathrm{m} \text {, with respect to } \mathrm{m},
$$

where

$\pi=$ net revenue to a given church or denomination

$\mathrm{D}=\mathrm{D}(\mathrm{E})=$ per member donations

$\mathrm{m}=$ number of church members in a given church or denomination

$\mathrm{C}=$ cost (assumed constant per member)

The basic objective function is extended to incorporate society-wide factors:

$$
\mathrm{E}=\mathrm{E}(\mathrm{M}, \mathrm{G}) \text {, }
$$

where

$\mathrm{E}=$ aggregate property rights enforcement

$\mathbf{M}=$ aggregate number of church members (the sum of m's)

$\mathrm{G}=$ other (e.g., government) property rights enforcement 
Donations per member are a function of the aggregate level of property rights enforcement, $D=D(E)$, in turn partly a function of the total number of church members, $E=E(M, G)$. Property rights enforcements affects donations directly to the extent church members perceive and reward church efforts to enforce property rights or affects donations indirectly if increased property rights enforcement causes individual incomes to increase in turn leading to increased donations. With subscripts denoting partial derivatives, the first order condition is the following:

$$
\pi_{\mathrm{m}}=\mathrm{D}_{\mathrm{E}} \mathrm{E}_{\mathrm{M}} \mathrm{m}+\mathrm{D}-\mathrm{C}=0 .
$$

A church equates the marginal cost of adding a new member with the donations from that member and any additional donations from all members due to improved property rights enforccment.

To maximize net revenue, the church devotes resources to attracting members. Aggregated across churches, these activities contribute to the overall level of property rights enforcement. Thus, "preaching matters". That is, the model links church maximizing behavior to church doctrine that enforces property rights, a valuable public good.

The theory asserts that aggregate church membership positively affects the level of property rights enforcement in a host society: $\mathrm{E}_{\mathrm{M}}>0$. L-M-T's regression model presumes a linear relationship between membership and property rights enforcement. More likely, however, the relationship is not linear, although the second order conditions do not restrict the shape of $E(M)$ :

$$
\pi_{\mathrm{mm}}=\mathrm{D}_{\mathrm{EE}} \mathrm{E}_{\mathrm{M}} \mathrm{E}_{\mathrm{M}} \mathrm{m}+\mathrm{D}_{\mathrm{E}} \mathrm{E}_{\mathrm{MM}} \mathrm{m}+\mathrm{D}_{\mathrm{E}} \mathrm{E}_{\mathrm{M}}<0 .
$$

Pats some point, additional members probably have diminishing marginal effect on enforcement $\mathrm{E}_{\mathrm{MM}}<0$. This is a diminishing "marginal product" argument. Once total membership is sufficient, property rights are well-protected and additional members have little impact. Further, although the model does not incorporate strength of helief, it seems plausible the marginal church memher has a less strong belief than infra-marginal members.

\section{Data and test}

The model predicts a positive but diminishing marginal relationship between total church membership and property rights enforcement. This suggests a straightforward regression equation with church membership as the independent variable and property rights enforcement as the dependent variable. Data for the former are available, but not explicitly for the latter. However, a reverse measure of the effectiveness of property rights enforcement is the crime rate. An increase in property rights enforcement implies, ceteris paribus, a lower crime rate.

The crime rate is not solely a function of religious membership, however. A substantial literature is devoted to the economic theory of crime, usually following 
the model of Becker (1968). Important examples include papers by Ehrlich (1975), Layson (1985), and Ehrlich and Brower (1987). These papers start with simultaneous equation models incorporating the demand for and supply of crime and address individual or general deterrence effects.

Integrating this work, Trumbull (1989) shows that single-equation OLS regression models perform as well as two-stage least squares versions (see also Layson (1985)). Trumbull applies these models to individual data and to aggregate data by county in North Carolina. The latter aggregate data explains overall crime rates rather than an individual's propensity to commit crime. This type of analysis is particularly useful given the evidence of Stark (1984) that the overall level of religious membership is more effective at influencing individual behavior (and thus crime rates) than is individual religious belief. L-M-T also review this literature and integrate a number of the standard additional independent variables. We follow their approach but use county level data.

The number of church adherents by county is taken from Churches and Church Membership in the U.S., 1980, compiled by Glenmary Research Center (1982). Other data come from the County and City Data Book, (1983 edition). Crime rates (reported as offenses per 100,000 population) are used as a (reverse) measure of the effectiveness of property rights enforcement. The extent of religion is measured in terms of the number of religious adherents as fractions of total county population.

The proposition that religion helps enforce property rights leads to the prediction that the regression coefficient for ADHERENTS is negative. To test the proposition of diminishing marginal effectiveness of church membership on property rights enforcement, we employ the quadratic variable ADHERENTS SQUARED. The predicted coefficient ADHERENTS SQUARED is positive.

Table 1 shows the results for regressions on three crime variables. The signs of the coefficients on ADHERENTS and ADHERENTS SQUARED are consistent with the theory and statistically significant. That is, as the fraction of a county's population that are church members increases, the county crime rate falls. Further, additional church members in a county have a diminishing marginal affect on the county crime rate. Coefficients on other independent variables are consistent with those of L-M-T and with common intuition. Crime rates are positively related to the unemployment rate, urban population, and population density and are negatively related to the white population proportion. Opposite of what we might expect, crime rates are positively related to personal income and police spending and are negatively related to the percent of the population below the poverty level. Although counter to intuition, the signs on these coefficients are the same as those reported by L-M-T and by the other aforementioned crime researchers and are a result of employing OLS equations in a situation where some factors appear in both the demand for and supply of enforcement. Finally, we include a HERFINDAHL INDEX variable, again following L-M-T's framework. The coefficients were not significant, generally paralleling L-M-T's results. 
Table 1

Regressions on crime and church adherents

\begin{tabular}{|c|c|c|c|}
\hline & \multicolumn{3}{|l|}{ Dependent variable } \\
\hline & TOTAL CRIME & VIOLENT CRIME & PROPERTY CRIME \\
\hline Constant & $\begin{array}{l}4454.5 \\
(9.88)\end{array}$ & $\begin{array}{l}643.3 \\
(12.3)\end{array}$ & $\begin{array}{l}3811.2 \\
(9.04)\end{array}$ \\
\hline ADHERENTS & $\begin{array}{l}-7619.6 \\
(-12.4)\end{array}$ & $\begin{array}{l}-696.3 \\
(-9.77)\end{array}$ & $\begin{array}{l}-6923.3 \\
(-12.1)\end{array}$ \\
\hline ADHERENTS SQUARED & $\begin{array}{l}4141.0 \\
(8.52)\end{array}$ & $\begin{array}{l}363.8 \\
(6.43)\end{array}$ & $\begin{array}{l}3777.2 \\
(8.31)\end{array}$ \\
\hline UNEMPLOYMENT RATE & $\begin{array}{l}75.66 \\
(7.46)\end{array}$ & $\begin{array}{l}3.69 \\
(3.13)\end{array}$ & $\begin{array}{l}71.97 \\
(7.59)\end{array}$ \\
\hline URBAN POPULATION \% & $\begin{array}{l}31.04 \\
(25.0)\end{array}$ & $\begin{array}{l}2.21 \\
(15.3)\end{array}$ & $\begin{array}{l}28.84 \\
(24.9)\end{array}$ \\
\hline PERSONAL INCOME & $\begin{array}{l}0.166 \\
(7.96)\end{array}$ & $\begin{array}{l}0.013 \\
(5.23)\end{array}$ & $\begin{array}{l}0.154 \\
(7.87)\end{array}$ \\
\hline POLICE SPENDING \% & $\begin{array}{l}213.1 \\
(10.6)\end{array}$ & $\begin{array}{l}18.79 \\
(8.03)\end{array}$ & $\begin{array}{l}194.33 \\
(10.3)\end{array}$ \\
\hline POPULATION DENSITY & $\begin{array}{l}0.166 \\
(4.76)\end{array}$ & $\begin{array}{l}0.072 \\
(17.7)\end{array}$ & $\begin{array}{l}0.094 \\
(2.89)\end{array}$ \\
\hline WHITE \% & $\begin{array}{l}-18.20 \\
(-7.10)\end{array}$ & $\begin{array}{l}-4.98 \\
(-16.7)\end{array}$ & $\begin{array}{l}-13.22 \\
(-5.51)\end{array}$ \\
\hline POVERTY \% & $\begin{array}{c}-47.92 \\
(-7.77)\end{array}$ & $\begin{array}{c}-0.615 \\
(-0.86)^{*}\end{array}$ & $\begin{array}{c}-47.31 \\
(-8.21)\end{array}$ \\
\hline HERFINDAHL INDEX & $\begin{array}{l}-64.90 \\
(-0.36)^{*}\end{array}$ & $\begin{array}{l}19.30 \\
(0.91)^{*}\end{array}$ & $\begin{array}{l}-84.20 \\
(-0.50)\end{array}$ \\
\hline$\overline{\mathbf{R}}^{2}$ & 0.507 & 0.455 & 0.495 \\
\hline
\end{tabular}

$\mathrm{n}=2977$. T-values in parentheses. All slope coefficients are significant at 0.01 (two-tailed) except where noted.

* Not statistically significant.

Variables: TOTAL CRIME: Total rate of serious crimes. VIOLENT CRIME: Murder, forcible rape, robbery, and aggravated assault. PROPERTY CRIME: Burglary, larceny-theft, and motor vehicle theft. ADHERENTS: Total church adherents divided by total population. ADHERENTS SQUARED: ADHERENTS squared. UNEMPLOYMENT RATE: Unemployment rate. URBAN POPULATION \%: Percent of population in urban areas. PERSONAL INCOME: Per capita personal income. POLICE SPENDING \%: Police expenditures as a percent of total government expenditures. POPULATION DENSITY: Population per square mile. WHITE \%: Percent of the population that are white. POVERTY \%: Percent of the population below the poverty level. HERFINDAHL INDEX: Sum of squared market shares of denominations. Share of denominations is calculated as denomination adherents divided by total adherents.

Overall, the statistical results are encouraging. The key coefficients are consistent with a model of church maximizing behavior. The results also strongly support L-M-T's conclusions while employing more appealing county-level data. 


\section{References}

Becker, Gary S., 1968, Crime and punishment: An economic approach, Journal of Political Economy 76, 169-217.

Ehrlich, Isaac, 1975, The deterrent effect of capital punishment: A question of life and death, American Economic Review 65, 397-417.

Ehrlich, Isaac and George D. Brower, 1987, On the issue of causality in the economic model of crime and law enforcement, American Economic Review 77, 99-106.

Ellickson, Robert C., 1991, Order without law; how neighbors settle disputes (Harvard University Press, Cambridge, Mass.).

Etzioni, Amitai, 1988, The moral dimension (The Free Press, New York).

Frank, Robert H., 1988, Passions within reason; the strategic role of the emotions (W.W. Norton, New York).

Glenmary Research Center, 1982, Churches and church membership in the United States, 1980 (Glenmary Research Center, Washington, D.C.).

Hull, Brooks B. and Frederick Bold, 1989, Towards an economic theory of the church, International Journal of Social Economics 16, 5-15.

Hull, Brooks B. and Frederick Bold, 1994, Hell, religion, and cultural change, Journal of Institutional and Theoretical Economics 150, 447-464.

Hull, Brooks B. and Gerald Moran, 1989, A preliminary time series analysis of church activity in colonial Woodbury Connecticut, Journal for the Scientific Study of Religion 28, 478-92.

Iannaccone, Laurence R., 1992, Sacrifice and stigma: Reducing free riding in cults, communes, and other collectives, Journal of Political Economy, 100, 271-292.

Layson, Stcphen K., 1985, Homicide and deterrence: A rexamination of the United States time-serics evidence, Southern Economic Journal 52, 68-89.

Lipford, Jody, Robert E. McCormick and Robert D. Tollison, 1993, Preaching matters, Journal of Economic Behavior and Organization 21, 235-250.

Sandler, Todd, 1992, Collective action: Theory and applications (University of Michigan Press, Ann Arbor, MI).

Sandler, Todd and John T. Tschirhart, 1980, The economic theory of clubs: An evaluative survey, Journal of Economic Literature 18, 1481-1521.

Stark, Rodney, 1984, Religion and conformity: Reaffirming a sociology of religion, Sociological Analysis 45, 273-82.

Trumbull, William N., 1989, Estimations of the economic model of crime using aggregate and individual level data, Southern Economic Journal 56, 423-39.

U.S. Department of Commerce, Bureau of the Census, 1983, County and city data book (U.S. Government Printing Office, Washington, D.C.).

Wilson, James Q., 1993, The moral sense (The Free Press, New York). 